\title{
Authors of Articles in Vol. II, No. 3
}

H. LEEMING, Lecturer in Comparative Slavonic Philology at the School of Slavonic and East European Studies, University of London.

ARNOLD B. McMILLIN, Lecturer in Russian Language and Literature at the School of Slavonic and East European Studies, University of London.

JAN ZAPRUDNIK, Assistant Professor of History at Queen's College, The City University of New York. 